\title{
The Histological Subtypes of Breast Cancer Seen in a Tertiary Hospital in South-East, Nigeria
}

\author{
Uzoigwe J. Chukwuma ${ }^{1}$, Nzegwu M. Arinze ${ }^{2}$, Onyishi N. Thaddeus ${ }^{3}$, Ekwedigwe C. Kenneth ${ }^{4}$, Edegbe O. Felix ${ }^{1}$, \\ Okani O. Chudi ${ }^{5}$, Ajah O. Leonard ${ }^{6} \&$ Ekwedigwe I. Paul ${ }^{4}$ \\ ${ }^{1}$ Department of Morbid Anatomy, Alex-Ekwueme Federal University Teaching Hospital, Abakaliki, Nigeria \\ ${ }^{2}$ Department of Morbid Anatomy, University of Nigeria Teaching Hospital, Ituku-Ozalla, Enugu, Nigeria \\ ${ }^{3}$ Department of Histopathology, Enugu State University College of Medicine, Parklane, Enugu, Nigeria \\ ${ }^{4}$ Department of Obstetrics and Gynaecology, Alex-Ekwueme Federal UniversityTeaching Hospital, Abakaliki, \\ Nigeria \\ ${ }^{5}$ Department of Histopathology, Chukwuemeka Odimegwu Ojukwu University, Awka Campus, Anambra, \\ Nigeria \\ ${ }^{6}$ Department of Obstetrics and Gynaecology, University of Nigeria Teaching Hospital, Ituku-Ozalla, Enugu, \\ Nigeria \\ Correspondence: Dr. Ekwedigwe Kenneth Chinedu, Department of Obstetrics and Gynaecology, Alex-Ekwueme \\ Federal University Teaching Hospital, Abakaliki, Ebonyi State, Nigeria
}

Received: January 1, 2020 Accepted: April 9, 2020 Online Published: April 20, 2020

doi:10.5539/gjhs.v12n6p93 URL: https://doi.org/10.5539/gjhs.v12n6p93

\begin{abstract}
Introduction: Breast cancer is a disease with heterogeneous nature that may have different prognosis and respond to therapy differently despite similarities in histological type, grade and stage. It is common among women in both developed and developing countries of the world.
\end{abstract}

Materials and Methods: This study was a 2-year retrospective study involving a systematic analysis of all the formalin-fixed paraffin-embedded tissue blocks previously diagnosed as breast cancers. The study occurred at the Department of Morbid Anatomy, University of Nigeria Teaching Hospital, Enugu. We retrieved all the archived tissue blocks and subjected them to further ancillary testing using the immunohistochemistry monoclonal antibodies: (Oestrogen receptors (ER), Progesterone receptors (PR) and Her-2 neu antibodies).

Results: Out of 417 cases of breast cancer analysed, four hundred and Ten (410) were females representing 98.3\%, seven (7) were males representing $1.7 \%$. The mean age of all subjects in this study was $45.1 \pm 10.2 \mathrm{SD}$ (years). The age of patients ranged from 20 to 70 years. The age group 31 to 40 years showed the highest number of cases, 133 (32.4\%). The cases positive for ER were 157 (37.6\%), while $260(62.4 \%)$ were negative. The cases positive for PR were $144(34.5 \%)$ and 273 (65.5\%) were negative. Fifty-four cases (12.9\%) were HER2-neu positive, 15 (3.6\%) were equivocal and could not be further analysed due to lack of the facility to do Fluorescence in-situ hybridisation, and $348(83.5 \%)$ were HER-neu negative. Phenotypic classification based on ER, PR, and Her2 immunohistochemistry showed 113 cases $(27.1 \%)$ were Luminal A, 45 cases $(10.8 \%)$ were Luminal B, 23 cases (5.5\%) were Her2 Enriched, 236 cases (56.6\%) were Basal-like/Triple-negative, and none (0\%) was Normal-like.

Conclusion: In conclusion, this study shows that Basal-like/Triple-negative breast cancers are most common and are seen more in premenopausal women in Enugu.

Keywords: Breast cancer, Hormone Receptor, Immunohistochemistry, Oestrogen Receptor (ER), Progesterone Receptor (PR), HER2-neu

\section{Introduction}

Breast cancer has remained a significant global health challenge. In most countries, the incidence is in the increase, and it is projected to peak over the next 20 years despite all the efforts with advanced researches to prevent the disease (Eccles et al., 2013; Arnold et al., 2015; Rahib et al., 2014; Colditz \& Bohlke, 2014).

It is not surprising to know that the incidence is increasing in most countries, because of an increase in numbers of 
women with significant breast cancer risk factors. These risk factors include lower age of menarche, late age of first pregnancies, shorter or no periods of breastfeeding, and later menopause. The other risk factors adding to the burden of breast cancers include obesity, sedentary lifestyle, hormone replacement therapy (HRT), and increased alcohol consumption (Colditz \& Bohlke, 2014). Also, the increase in the impact of hereditary breast cancer is evident. For example, the body of literature suggested that the penetrance of susceptibility to breast cancer gene-2 (BRCA2) mutation in Iceland increased fourfold over the last century and cumulative incidence of sporadic breast cancer by age 70 also increased fourfold, from $2.5 \%$ to $11 \%$ of the population, over the same period (Tryggyadottirl et al., 2006). This data suggest that both familial and non-familial risk has increased.

Nevertheless, reports based on immunohistochemistry (IHC) or expression array analysis have shown that BRCA2 breast tumours are predominantly of Luminal B subtype (Bane et al., 2007; Larsen et al., 2013). These are more likely than non-BRCA2 tumours to be ER-positive and high grade with the reduced tubular formation and continuous pushing margins (Bane et al., 2007). Researchers have also shown that the frequency of triple-negative breast cancers was high in indigenous African women, suggesting that there must be environmental, genetic or both factors that influence the frequency of the subtypes in different populations (Olopade, Fackenthi, \& Dunston, 2002).

In Nigeria, according to the Hospital-based Cancer Registries (HBCR), breast cancer was far the most common cancer in women constituting $40.3 \%$ of all cancers followed by cervical cancer (17.3\%) (Adebamowo \& Akarolo-Anthony, 2009; Adebamowo \& Ajayi, 2000; Akarolo-Anthony, Ogundiran, \& Adebamowo 2010).

Population-based cancer registries in Nigeria (PBCR) also suggest that breast cancer is the most prevalent cancer in Nigerian women. Incidence of breast cancer in Nigeria is expected to continue to rise with increasing life expectancy, change in obstetrics and gynaecology practices, diet and physical activity (Adebamowo \& Akarolo-Anthony, 2009; Adebamowo \& Ajayi, 2000; Akarolo-Anthony, Ogundiran, \& Adebamowo, 2010). .

A ten-year-study done on Breast lesions by Nzegwu et al. from 1998-2007 in University of Nigeria Teaching Hospital (UNTH) Enugu showed that breast cancer constituted 29.4\%, thus the most frequent malignancy in females and the most common cause of cancer mortality in women in south-Eastern Nigeria (Nzegwu et al., 2008).

Similar to other types of human cancer, breast carcinoma development likely follows a multistep process of activation of oncogenes and inactivation of tumour suppressor genes by aberrant promoter methylation (Kern, 2001). Hypermethylation is a fundamental process involved in the development of many malignant tumours, including breast cancer (Baylin \& Cheny, 2005). This promoter methylation is not randomly distributed in carcinogenesis as the case may be, but it is gene-specific and cancer type-specific (Risinger et al., 2003; Toyooka et al., 2003; Gonzalgo, Yegnasubramarian, \& Yan, 2014).

In breast cancer, several genes have been identified as differently methylated in specific histologic subtypes (Bae et al., 2004; Lehmann et al., 2002; Fackler et al., 2003; Tisserand et al., 2003).

However, the association between promoter methylation and the distinct molecular subtypes of breast cancer has not been well investigated (Magdinier et al., 1998; Catteau et al., 1999; Esteller et al., 2000; Matros et al., 2005; Turner et al., 2007; Beteolo et al., 2008).

Molecular subtyping of breast cancer in the developed world (USA) has led to decline in breast cancer mortality which has been attributed to the combination of early detection with screening programs and advent of more efficacious adjuvant systemic therapy (Goldhirsch et al., 2013). The continued advances in understanding the molecular subtyping of breast cancer have aided in the discovery of novel pathway-specific targeted therapeutics. Moreover, the emergence of such effective therapeutics is currently driving the need for molecular-based "patient-tailored" treatment planning in the developed world (Goldhirsch et al., 2013).

The seemingly increased prevalence of breast lesions, especially the malignant breast disease over the years with its attendant poor prognosis and their relative late presentations, coupled with reduced life expectancy at 47 (Nzegwu et al., 2008), calls for an urgent and more serious approach to management, prevention, and control, thus necessitating this study.

The invasive breast cancers will be molecularly subtyped based on their staining response to rabbit monoclonal antibodies: Oestrogen receptor (ER), Progesterone receptor (PR), and Her-2 neu antibodies; using paraffin-embedded formalin-fixed tissue blocks.

\section{Materials and Methods}

All the Formalin-fixed paraffin-embedded tissue blocks performed between the periods, January 2015 and December 2016 were obtained from the archive of the Department of Morbid Anatomy, University of Nigeria 
Teaching Hospital, Enugu. The case to study composed of all diagnosed breast cancers, one representative block was selected from each case if more than one block were retrieved from the archive. The histological classification of breast cancer was extracted from the 2013 WHO classification of breast diseases (Devilee \& Tavassoli, WHO, 2013; Rossai, 2004). A total of 417 samples of breast cancers over the two years were analysed into molecular subtypes based on their staining response to rabbit monoclonal antibodies: (Oestrogen receptors (ER), Progesterone receptors (PR) and Her-2 neu antibodies). Results of these samples and slides were collated and subsequently analysed.

The surgical specimen tumour register in Pathology Department of University of Nigeria Teaching Hospital Enugu was consulted and histology slides were retrieved from the archives and were reviewed by the investigator and two consultant pathologists to confirm a breast cancer diagnosis. The corresponding tissue blocks of the confirmed cases were retrieved from the archives, and new 2-4 $\mu \mathrm{m}$ sections were taken, and immunostaining was done for Oestrogen, Progesterone and Her2/neu. All monoclonal antibodies used were procured from Bio Sb Inc USA as predilute ready to use and stored at a cold chain of 2-8 degree centigrade until they were used for typing. The combination of Immunohistochemical markers used to define breast cancer molecular subtypes by Perou et al. was used in this study. They are as follows: Luminal A (ER-positive, PR positive, or both ER and PR being positive and Her2 negative), Luminal B (ER-positive, PR positive, Her2 positive), Her-2 Enriched (ER-negative, PR negative, Her2 positive) Basal-like/Triple-negative (ER-negative, PR negative, Her2 negative) and Normal-like (ER-positive, PR positive, both ER and PR positive, Her2 negative) subtypes.

In each of the stainings ran, positive controls were included. These positive controls consisted of breast cancers known to express each of the antigens of interest. In this study, immunostaining was done for Oestrogen receptor (ER), Progesterone receptor (PR), Human epidermal growth factor 2 (Her-2/neu), using the manufacturer's antibodies and protocol. For each ER/PR immunohistochemically stained slide, there was a visual estimation of the percentage of tumour cells showing nuclear immunoreactivity. Cases were considered positive for ER and PR according to standardised guidelines using the Allred scoring system. An Allred score which is a semi-quantitative system. It takes into cognisance the proportion of positive cells on the histology slide (scored on a scale of 0-5) and staining intensity (scored on a scale of 0-3) was used for each case. The proportion and intensity of stained tumour nuclei were combined to produce total scores of 0 or 2 through 8 . A score of $0-2$ was interpreted as a negative result while 3-8 as positive (Allred et al., 2010).

HER2/neu was scored as $0,1+, 2+$ and $3+$ using the College of American Pathology Guidelines [35]. In line with this, $3+$ represented uniform intense membrane staining of more than $30 \%$ of the tumour cells and were considered positive for Her $2 /$ neu overexpression. Scores of 0 and $1+$ were read as negative score; Score $2+$ was considered as borderline or equivocal. Also, the American Society of Clinical Oncology/College of American Pathologist (ASCO/CAP) Guidelines recommended fluorescence in situ hybridisation (FISH) confirmation of all cases judged to be 2+ by immunohistochemistry (Wolff et al., 2013). This was not done in this study for reasons of lack of the facility and resources for FISH in Nigeria. Approval had been obtained from the Research Ethics Committee of the University of Nigeria Teaching Hospital to meet the ethical guidelines to enable the study to be carried out.

Cases established as breast cancers, diagnosis verified by at least two pathologists with complete patient data are included while cases excluded were poorly fixed and processed cases which were not likely to give optimal staining on immunohistochemistry, cases with incomplete patient data and all the cases that the tissue blocks could not be retrieved from the Departmental archive or store.

However, from the population-based statistical analysis, the minimum sample size required for this study was 95 . The data collected were analysed using International Business Machine, Statistical Package for Social Sciences (IBM SPSS) window version 23. Relevant means and frequencies were presented in tables, figures and summary indices. Inferential statistics (bivariate analysis) was also done using a chi-square test. P-value $<0.05$ was considered significant.

\section{Results}

A total of 417 cases of breast cancer were analysed in the study period. Immunohistochemistry was done on all these cases. Females accounted for the overwhelming majority with 410 cases $(98.3 \%)$ while males accounted for 7 cases $(1.7 \%)$.

The mean age of all subjects in this study was $45.1 \pm 10.2 \mathrm{SD}$ (years). The age ranged from 20 to 70 years. In males, the age group 41 to 50 years accounted for the highest number of cases 4 (57. 1\%), followed by the 31 to 40 years age group which accounted for 2 cases (28.6\%). In females, the 31 to 40 years age group accounted for the highest number of cases $133(32.4 \%)$, followed by the 41 to 50 years age group which accounted for 118 cases (28.8\%). 
Distribution of the cases in these age groups and others can be seen in (Tables 1 and 2 respectively).

Table 1. Sex and Age Distribution of Cases in Males

\begin{tabular}{lll}
\hline Age Category (Years) & Frequency & Percentage (\%) \\
\hline $20-30$ & 0 & 0 \\
$31-40$ & 2 & 28.6 \\
$41-50$ & 4 & 57.1 \\
$51-60$ & 1 & 14.3 \\
$61-70$ & 0 & 0 \\
$>70$ & 0 & 0 \\
\hline Total & $\mathbf{7}$ & $\mathbf{1 0 0}$ \\
\hline Mean age (yrs) & $\mathbf{4 4}$ & \\
Standard Deviation & $\mathbf{7 . 9}$ & \\
\hline
\end{tabular}

Table 2. Sex and Age Distribution of Cases in Females

\begin{tabular}{lcc}
\hline Age Category (Years) & Frequency & Percentage (\%) \\
\hline $20-30$ & 23 & 5.6 \\
$31-40$ & 133 & 32.4 \\
$41-50$ & 118 & 28.8 \\
$51-60$ & 87 & 21.3 \\
$61-70$ & 39 & 9.5 \\
$>70$ & 10 & 2.4 \\
\hline Total & $\mathbf{4 1 0}$ & $\mathbf{1 0 0}$ \\
\hline Mean age (yrs) & $\mathbf{4 6 . 1}$ & \\
Standard Deviation & $\mathbf{1 2 . 4}$ & \\
\hline
\end{tabular}

The histologic diagnosis of most of the cases was infiltrating/invasive ductal carcinoma. These carcinomas accounted for 325 cases (77.9\%), followed by lobular carcinoma, which accounted for 63 cases (15.1\%). The least of the cases were mucinous and cribriform carcinomas which accounted for 2 cases $(0.5 \%)$ respectively as shown in (Table 3).

Table 3. Distribution of histological subtypes of breast cancer

\begin{tabular}{lll}
\hline Diagnosis & Frequency & Percentage (\%) \\
\hline IDC & 325 & 77.9 \\
ILC & 63 & 15.1 \\
Mucinous Carcinoma & 2 & 0.5 \\
Metaplastic Carcinoma & 10 & 2.4 \\
Papillary Carcinoma & 6 & 1.4 \\
Tubular Carcinoma & 9 & 2.2 \\
Cribriform Carcinoma & 2 & 0.5 \\
\hline Total & $\mathbf{4 1 7}$ & $\mathbf{1 0 0}$ \\
\hline
\end{tabular}

Key: IDC = Invasive ductal carcinoma, ILC = Invasive lobular carcinoma. 
The cases positive for Oestrogen Receptor (ER) were 157 (37.6\%), while 260 (62.4\%) were negative. The cases positive for Progesterone Receptor (PR) were 144 (34.5\%), and 273 (65.5\%) were negative. Fifty-four cases (12.9\%) were positive for Her2 Receptors, 348 (83.5\%) were negative, and 15 (3.6) were equivocal. The equivocal cases were not further analysed using Fluorescence In-situ hybridisation as a facility for this was not available in our centre. Oestrogen, Progesterone, and Her2-neu receptors were higher between the ages of 31 to 50 years. The differences in number of positive receptors among different age groups were statistically significant as follows: Oestrogen $(\mathrm{X} 2=16.3, \mathrm{p}=0.006)$, Progesterone $(\mathrm{X} 2=33.7, \mathrm{p}=0.001)$ and Her2-neu $(\mathrm{X} 2=32.8, \mathrm{p}=0.001)$ (Table 4).

Table 4. Status of Oestrogen Receptor, Progesterone Receptor, Her2/neu and Age Relationship

\begin{tabular}{|c|c|c|c|c|c|c|}
\hline \multirow{3}{*}{$\begin{array}{l}\text { Age of the patients } \\
\text { (Years) }\end{array}$} & \multicolumn{4}{|c|}{ Oestrogen Receptor $n=417$} & \multirow{3}{*}{$X^{2}$} & \multirow{3}{*}{$\boldsymbol{P}$} \\
\hline & Positive & \multicolumn{3}{|c|}{ Negative } & & \\
\hline & $\mathbf{N}$ & $\%$ & $\mathbf{N}$ & $\%$ & & \\
\hline $20-30$ & 15 & 65.2 & 8 & 34.8 & \multirow{6}{*}{16.3} & \multirow{6}{*}{0.006} \\
\hline $31-40$ & 46 & 34.1 & 89 & 65.9 & & \\
\hline $41-50$ & 53 & 43.4 & 69 & 56.6 & & \\
\hline $51-60$ & 27 & 30.7 & 61 & 69.3 & & \\
\hline $61-70$ & 10 & 25.6 & 29 & 74.4 & & \\
\hline$>70$ & 6 & 60.0 & 4 & 40.0 & & \\
\hline \multirow[t]{2}{*}{ Total } & 157 & & 260 & & & \\
\hline & \multicolumn{4}{|c|}{ Progesterone Receptor $n=417$} & $X^{2}$ & $P$ \\
\hline $20-30$ & 17 & 73.9 & 6 & 26.1 & \multirow{6}{*}{33.7} & \multirow{6}{*}{0.001} \\
\hline $31-40$ & 60 & 44.4 & 75 & 55.6 & & \\
\hline $41-50$ & 30 & 24.6 & 92 & 75.4 & & \\
\hline $51-60$ & 20 & 22.7 & 68 & 77.3 & & \\
\hline $61-70$ & 12 & 30.8 & 27 & 69.2 & & \\
\hline$>70$ & 5 & 50.0 & 5 & 50.0 & & \\
\hline \multirow[t]{2}{*}{ Total } & 144 & & 273 & & & \\
\hline & \multicolumn{3}{|c|}{ Her-2 neu Receptor $n=402$} & & $X^{2}$ & $P$ \\
\hline $20-30$ & 10 & 47.6 & 11 & 52.4 & \multirow{6}{*}{32.8} & \multirow{6}{*}{0.00} \\
\hline $31-40$ & 23 & 17.6 & 108 & 82.4 & & \\
\hline $41-50$ & 15 & 13.0 & 100 & 87.0 & & \\
\hline $51-60$ & 3 & 3.5 & 83 & 96.5 & & \\
\hline $61-70$ & 2 & 5.1 & 37 & 94.9 & & \\
\hline$>70$ & 1 & 10.0 & 9 & 90.0 & & \\
\hline Total & 54 & & 348 & & & \\
\hline
\end{tabular}

Phenotypic classification based on ER, PR, and Her2 immunohistochemistry showed 236 cases $(56.6 \%)$ to be Basal-like/Triple Negative, 113 cases (27.1\%) were Luminal A, 45 cases (10.8\%) were Luminal B, 23 cases (5.5\%) were Her2-Enriched/ over-expressed, and $0(0 \%)$ were Normal-like subtypes. The distributions of the molecular subtypes were illustrated in (Table 5, Figure-1). The differences observed in the molecular subtypes among males and females were illustrated in Table 6 and Figure 2. However, it was observed that these differences were not significant statistically $(\mathrm{X} 2=3.469, \mathrm{p}=0.325)$. 
The basal-like/Triple Negative phenotype was relatively high across different age groups compared to other molecular subtypes, and these variations were statistically significant $(X 2=33.8, p=0.004)$ as illustrated in Table 7 and Figure-3). Photomicrograph showed the immunohistochemical status (positivity and negativity) for Oestrogen receptor status, progesterone receptor, and Her2-neu expression in breast tissue with invasive ductal carcinoma (Figures 4 and 5).

Table 5. Status of molecular subtypes

\begin{tabular}{lll}
\hline Molecular subtype & Frequency & Percentage (\%) \\
\hline Luminal A & 113 & 27.1 \\
Luminal B & 45 & 10.8 \\
Her-2 Enriched & 23 & 5.5 \\
$\quad$ Basal-like/Triple Negative & 236 & 56.6 \\
Normal-like & 0 & 0 \\
\hline Total & $\mathbf{4 1 7}$ & $\mathbf{1 0 0}$ \\
\hline
\end{tabular}

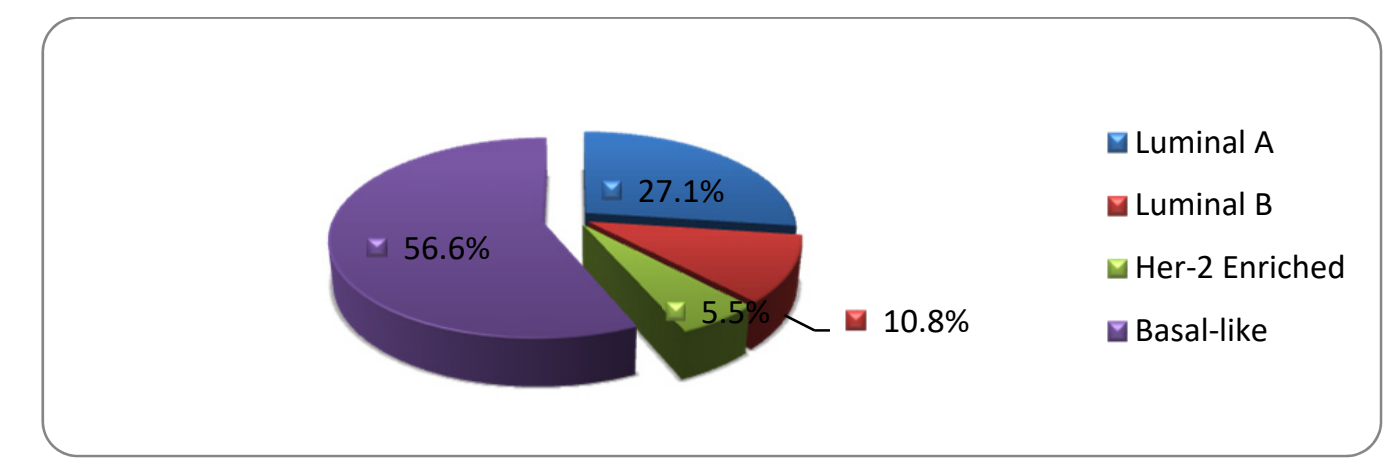

Figure 1. Pie chart of different molecular subtypes

Table 6. Molecular subtype and sex relationship

\begin{tabular}{|c|c|c|c|c|c|}
\hline Variables & Categories & Frequency & Percentage & $X^{2}$ & $P$ \\
\hline \multirow{2}{*}{ Luminal A } & Female & 113 & 100 & \multirow{10}{*}{3.469} & \multirow{10}{*}{0.325} \\
\hline & Male & 0 & 0 & & \\
\hline \multirow{2}{*}{ Luminal B } & Female & 44 & 97.8 & & \\
\hline & Male & 1 & 2.2 & & \\
\hline \multirow{2}{*}{ Her-2 Enriched } & Female & 23 & 100 & & \\
\hline & Male & 0 & 0 & & \\
\hline \multirow{2}{*}{ Basal-like/Triple Negative } & Female & 230 & 97.5 & & \\
\hline & Male & 6 & 2.5 & & \\
\hline \multirow{2}{*}{ Normal-like } & Female & 0 & 0 & & \\
\hline & Male & 0 & 0 & & \\
\hline
\end{tabular}




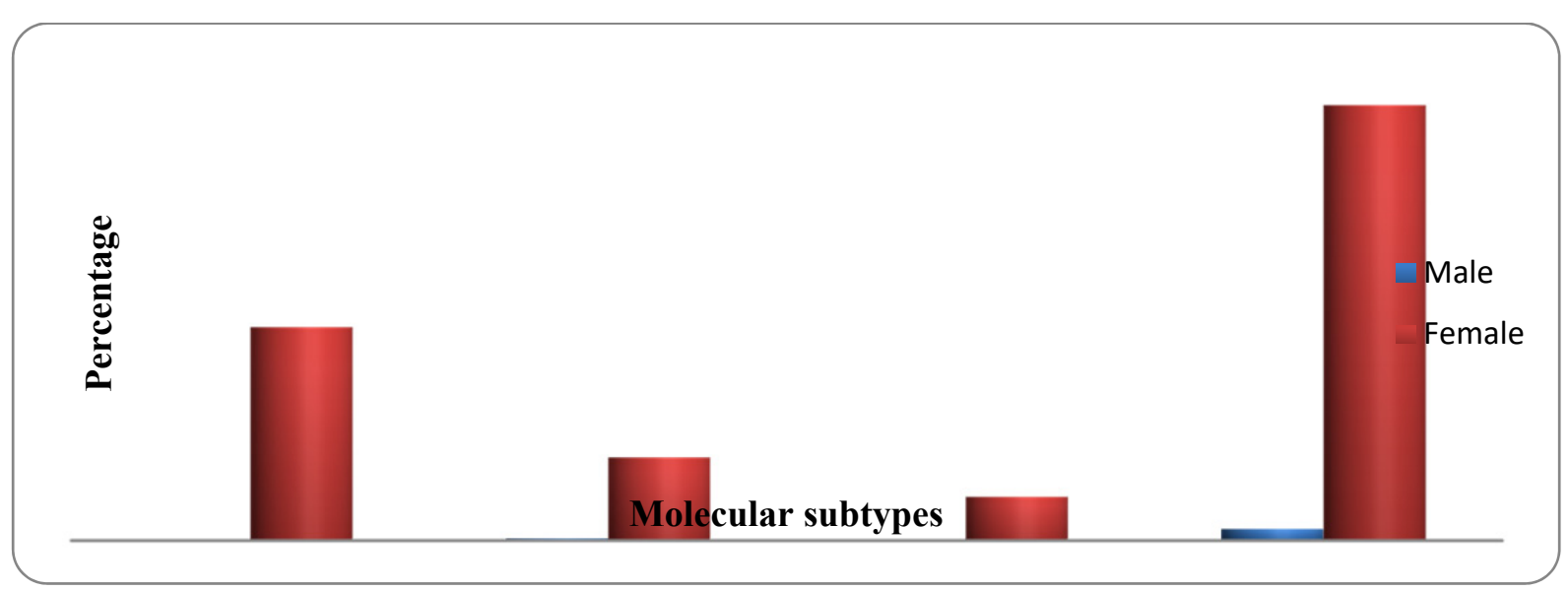

Figure 2. Molecular subtypes in relation to sex

Table 7. Molecular subtype and age relationship

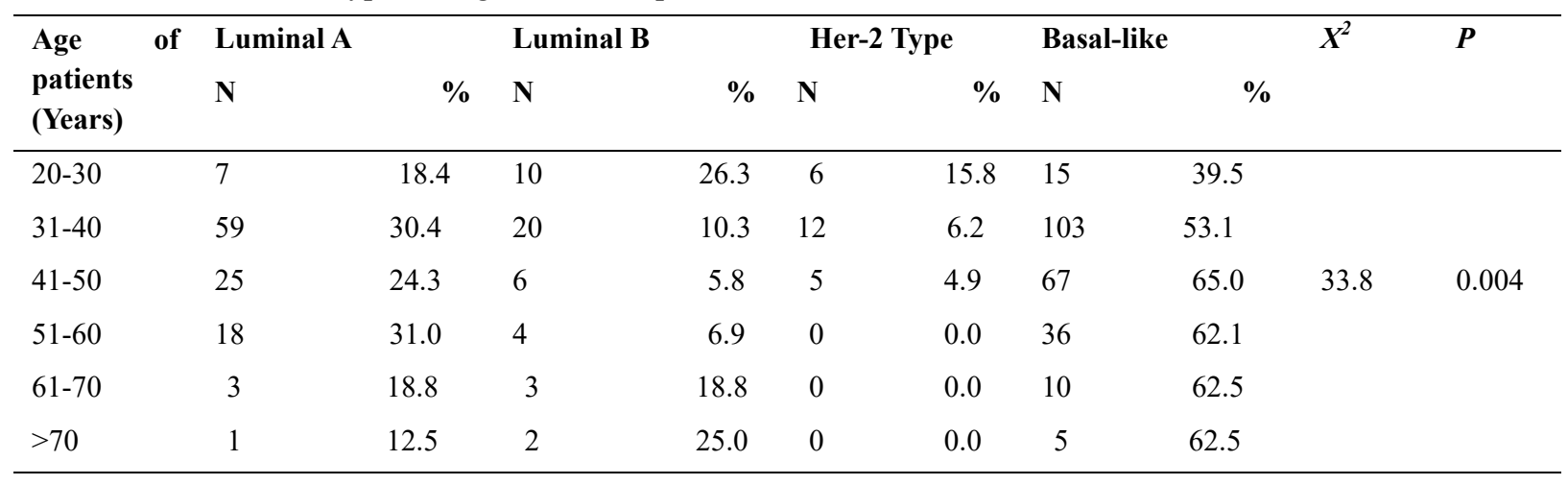

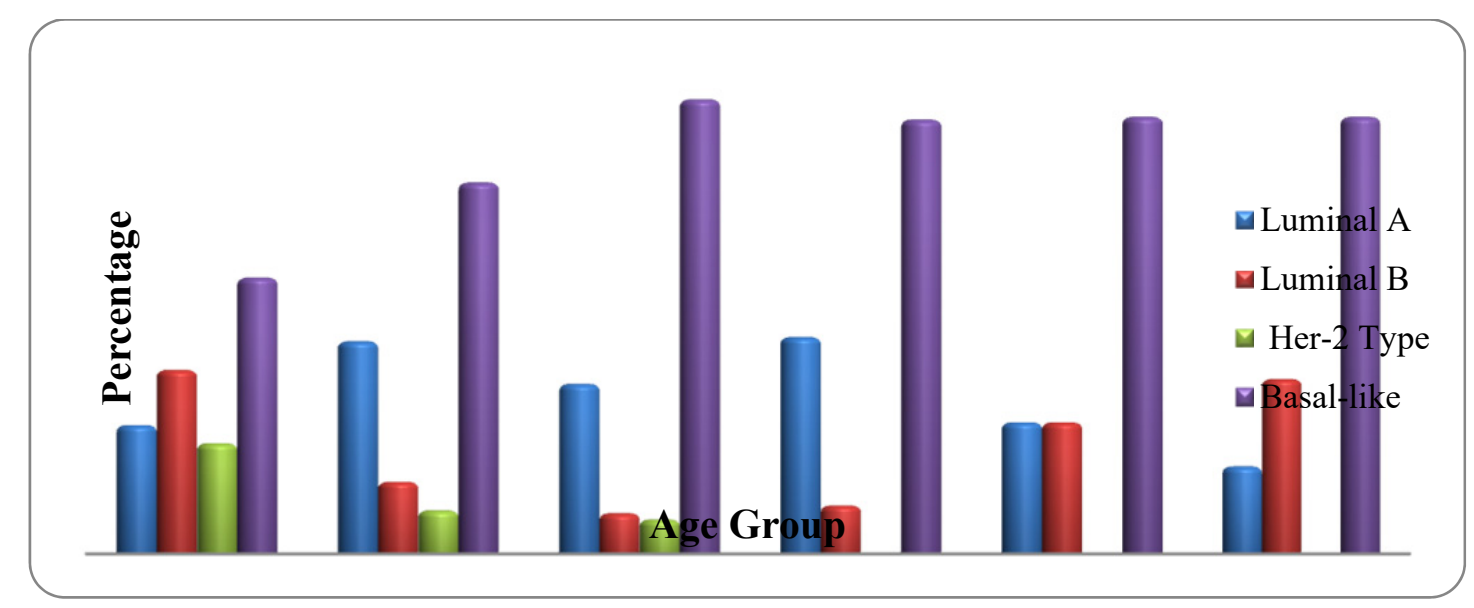

Figure 3. Molecular subtypes in relation to Age groups 

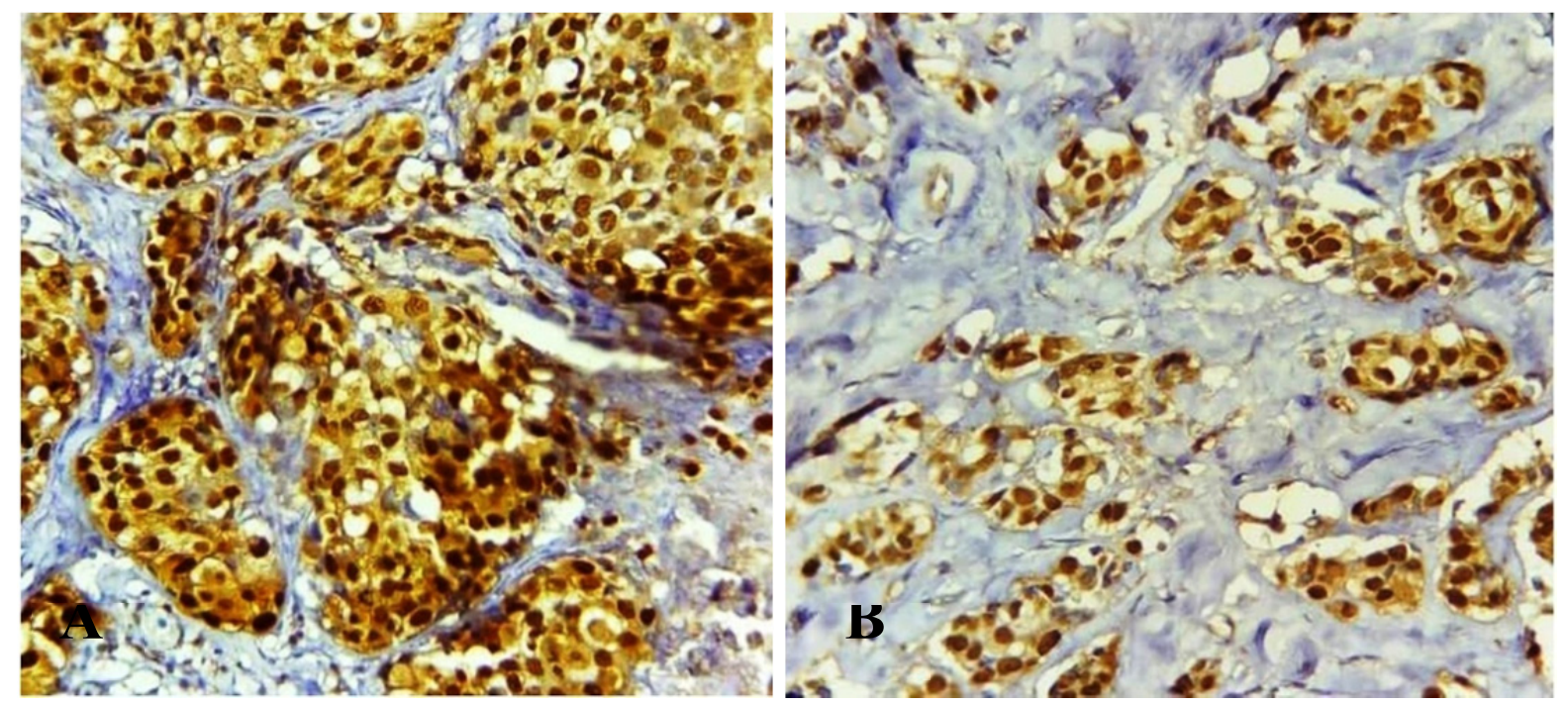

Figure 4. A, Photomicrographs of IDC showing positive nuclei staining for Oestrogen Receptor (Original magnification $\times 100)$. B, Photomicrograph of IDC showing positive nuclei staining for Progesterone Receptor (Original magnification $\times 100)$
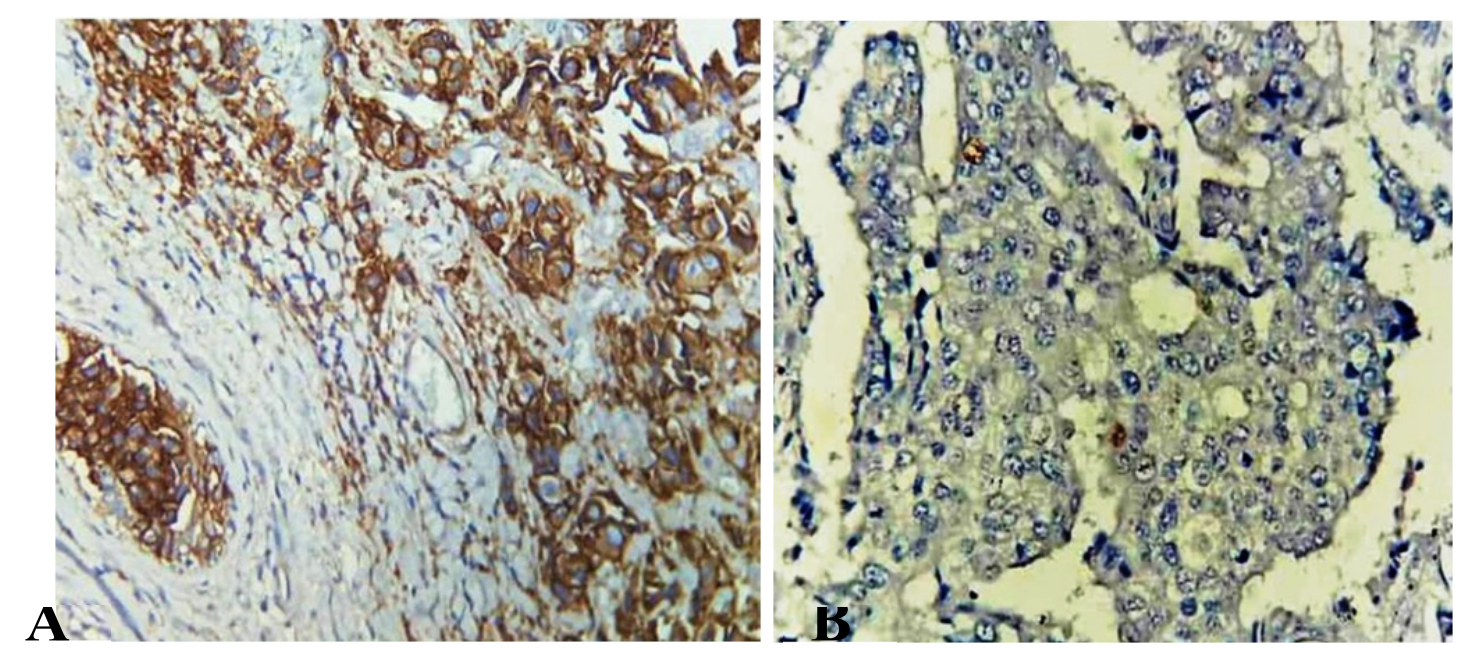

Figures 5. A, Photomicrograph of IDC showing Her2+++ (Original magnification $\times 100)$ and Photomicrograph of IDC showing Oestrogen. B, Progesterone Receptors (Original magnification $\times 100$ )

\section{Discussion}

This study showed the mean age of breast cancer to be $45.1 \pm 10.2 \mathrm{SD}$ (years) and the 31 to 40- year age group to have the highest number of cases. Females were found to be comparatively much more affected by breast cancer, with only $1.7 \%$ found in males. The mean age is similar to the mean age of 41.6 years documented in another study on breast cancer done in our centre (Nzegwu et al., 2008). It is similar to the mean ages of 46.7 years, 48 years and 49.5years reported in the northeastern and south southern parts of Nigeria, respectively (Imam et al., 2017; Oboma et al., 2017; Nwafor \& Keshinro, 2015), but differs from the mean ages of 50.7 years and 52.5 years reported in southwestern Nigeria and Ghana respectively (Omoniyi Esan et al., 2015; Seshie et al., 2015). The mean age in this study also differs from the mean age of 56.5\% reported in Western countries like the USA (Carey et al., 2006). This might be as a result of better diagnostic facilities that will enable early diagnosis and treatment.

The age distribution of cases of breast cancer in this study showed that females in their reproductive age (young age group) were mostly affected; therefore, there should be an efficient and widely accessible screening programme to encourage early diagnosis and treatment. Although females are relatively overwhelmingly affected by breast cancer, finding cases in males makes it necessary to re-emphasize that they can also develop the disease. It is important to note that breast cancer in males in Nigeria had been associated with poor prognosis (Ahmed et al., 
2012).

The result of the Immunohistochemical pattern of breast cancer in this study revealed that Oestrogen Receptor was positive in 37.6\% (157), Progesterone Receptor was positive in 34.5\% (144) while Her2-neu Receptor was positive in only $12.9 \%$ (54) of cases. Similar results were recorded in a study done on immunohistochemical pattern of Breast cancer in northeastern Nigeria, by Imam et al. were $45.2 \%$ of 152 cases were positive for Oestrogen Receptor, 32.2\% were positive for Progesterone Receptor, and 22.6\% were positive for Her2-neu Receptor (Imam et al., 2017). But different from the report of Nwofor et al. 2014 with Oestrogen Receptor positive in $54.2 \%$ cases while Progesterone was seen in $50 \%$ with Her2 present in $31 \%$. In Southwestern Nigeria, a study carried out by Omoniyi-Esan et al. (Omoniyi Esan et al., 2015) reported Oestrogen Receptor positivity in 34.6\%, Progesterone Receptor positivity in $25 \%$ and Her2-neu Receptor positivity in $38.2 \%$ which is also similar to this study. In Ghana, it was reported an Oestrogen Receptor, Progesterone Receptor and Her2-neu Receptor positivity of $32.1 \%, 25.6 \%$, and $22.5 \%$ (Seshie et al., 2015). Recently in Al Khobor, Saudi Arabia the rate of positive hormone receptor and Her2 in breast cancer using Immunohistochemistry were $69.2 \%, 61.5 \%$, and $25.1 \%$ for Oestrogen Receptor, Progesterone Receptor and Her2-neu Receptor respectively (Imam et al., 2017), which is different from the results obtained in this study. The low rate of Immunohistochemical staining positive for Oestrogen Receptor, Progesterone Receptor and Her2-neu Receptor in Southeastern Nigeria is almost in harmony and fall in the same range of other populations in Nigeria (Nwafor \& Keshinro, 2015) and Ghana (Seshie et al., 2015). On the other hand, the rate of positivity in Oestrogen Receptor, Progesterone Receptor, and Her2-neu Receptor in western countries like USA (Rosnar et al., 2013) showed a high rate of positivity $(81 \%, 65 \%$, and $20 \%$ for ER, PR, and Her2-neu respectively). Alternatively contributing factor to those findings could be biological and lifestyle pattern. In this study, there is a significant association between the ages of the patients and hormone receptor status. In this study, Immunopositivity of breast carcinoma for Her2-neu among subjects was $12.9 \%$ and is similar to previous works done in Nigeria, $17.1 \%, 8.2 \%$, and $12.5 \%$ documented in Southwestern and south southern Nigeria respectively (Nwafor \& Keshinro, 2015; Omoniyi Esan et al., 2015; Olopade, Oluwasola, \& Ebili, 2014). The value of the present study is within the range of 10 to $25 \%$ documented in most studies worldwide.

In the molecular subtypes of this study, it was observed that Basal-like/Triple-negative cases 236 (56.6\%) accounted for the highest proportion of all cases. This conforms to reports from other studies in Nigeria (Imam et al., 2017; Omoniyi Esan et al., 2015; Titiloye et al., 2016). It was also observed that Triple-negative breast cancer cases were high among females of young age group, this is similar to other studies from Nigeria and United States in which high-grade triple-negative breast cancer was predominant (Titiloye et al., 2016) and Carey et al. also reported that Triple-negative breast cancers are frequently seen in premenopausal African women (39\%) compared with postmenopausal African-women (14\%) or women of any age who are not African-American (16\%) (Carey et al., 2004). Although the terms triple-negative breast cancer (TNBC) and basal-like cancer are often used interchangeably, it is important to clarify that not all Triple-negative Breast cancers belong to basal-like subtype (Carey et al., 2004). Triple-negative breast cancer (TNBC) is a subtype of breast cancer defined by the absence of the hormone receptors for Oestrogen and Progesterone, as well as a lack of expression of a cancer-promoting protein known as Her2-neu. The prevalence of Triple-negative subtype was also reported in Ghana (49.4\%) compared to other subtypes (Seshie et al., 2015). However, in contrast to some studies from south southern Nigeria, in which the majority of tumours was Luminal A and was documented as follows; $54.1 \%$, and $39.6 \%$ respectively (Oboma et al., 2017; Nwafor \& Keshinro, 2015). In this study, Luminal A was second highest accounting for (27.1\%) 113 cases. Carey et al. stated that Luminal A breast cancers have $>95 \%$ Oestrogen Receptor positive, meaning that their reaction to Oestrogen Receptor are strongly positive while Luminal B has about $40 \%$ to $60 \%$ Oestrogen Receptor, they show low to moderate Oestrogen Receptor positive reactions. Luminal A > Luminal B (Carey et al., 2006).

Based on both molecular testing and Immunohistochemical surrogates, some Low incidence countries have demonstrated a higher proportion of Luminal B over Luminal A and other molecular subtypes of breast cancers. These countries include Colombia [Age Standardized Incidence] (ASI, 39.7) and China (ASI, 31.7) (Huang et al., 2015; Serano-Gomez et al., 2015; Calvalho et al., 2014).

The relatively higher incidences of Luminal B breast cancers observed in developing countries may have a direct relationship between the younger populations and relatively small proportions of ageing women exposed to premenopausal hyperestrogenism (Rumak et al., 2017). Similarly, two recent studies found an increased prevalence of Luminal B subtypes in European (57.1\%) and Chinese (68.5\%) women respectively, when breast cancer classification was performed using the recommendations of the 2013 St. Gallen surrogates (Goldhirsch et al., 2013). These were not in agreement with what was done in this study, where the predominance of 
Triple-negative had been documented. The possibility that high prevalence of Triple-negative in Southeastern Nigeria might be due to differences in classification method between this study and those conducted in other populations. Also, there could be interlaboratory variation in the evaluation of Oestrogen Receptor, Progesterone Receptor and HER2/neu. In this study, no single case of normal breast-like subtype was found, since the study is based on only Immunohistochemistry (IHC) and not genetic profiling to determine which of the tumours expresses the epithelial genes of a normal breast.

\section{Conclusion}

In this study, positive contributions to the body of growing literature that classifies invasive breast tumours into various Immunohistochemistry subtypes similar to that identified by gene expression profiling are made. From this research, it shows that Basal-like/Triple-negative breast cancer is more common than all the other subtypes and is seen more in premenopausal women in Enugu. This is in agreement to most of the studies done in Nigeria. Also, revealed in this study is the preponderance of Basal-like/Triple-negative breast cancer in men of southeastern Nigeria, in contrast, to result from elsewhere, which reports Luminal A as more common in men.

\section{Acknowledgements}

We are grateful to the hospital management for giving us the permission to carry out the study in our hospital.

\section{Competing Interests Statement}

The authors declare that there are no competing or potential conflicts of interest. There was no grant or funding for the study.

\section{References}

Allred, D. C., Hammond, M. E., Dowsett, M., Hayes, D. F., Hagerty, K. L., Hicks, D. G., et al. (2010). Guideline Recommendations for Immunohistochemical Testing of Oestrogen receptor and Progesterone receptor in Breast Cancer: American Society of Clinical Oncology/College of American Pathologists. Journal of Clinical Oncology, 28, 2784-2795.

Adebamowo, C. A., \& Ajayi, O. O. (2000). Breast cancer in Nigeria. West African journal of medicine, 19(3), 179-191.

Adebamowo, C. A., \& Akarolo-Anthony, S. (2009). Cancer in Africa: opportunities for collaborative research and training. Afr J Med Med Sci, 38(Suppl 2), 5-13.

Ahmed, A., Ukwenya, Y., Abdullahi, A., \& Muhammad, I. (2012). Management and outcomes of male breast cancer in Zaria, Nigeria. International journal of breast cancer, 2012. https://doi.org/10.1155/2012/845143

Akarolo-Anthony, S. N., Ogundiran, T. O., \& Adebamowo, C. A. (2010). Emerging breast cancer epidemic: evidence from Africa. Breast cancer research, 12(4), S8. https://doi.org/10.1186/bcr2737

Arnold, M., Karim-Kos, H. E., Coebergh, J. W., Byrnes, G., Antilla, A., Ferlay, J., ... \& Soerjomataram, I. (2015). Recent trends in incidence of five common cancers in 26 European countries since 1988: Analysis of the European Cancer Observatory. European journal of cancer, 51(9), 1164-1187. https://doi.org/10.1016/j.ejca.2013.09.002

Bae, Y. K., Brown, A., Garrett, E., Bornman, D., Fackler, M. J., Sukumar, S., ... \& Gabrielson, E. (2004). Hypermethylation in histologically distinct classes of breast cancer. Clinical Cancer Research, 10(18), 5998-6005. https://doi.org/10.1158/1078-0432.CCR-04-0667

Bane, A. L., Beck, J. C., Bleiweiss, I., Buys, S. S., Catalano, E., Daly, M. B., ... \& John, E. M. (2007). BRCA2 mutation-associated breast cancers exhibit a distinguishing phenotype based on morphology and molecular profiles from tissue microarrays. The American journal of surgical pathology, 31(1), 121-128. https://doi.org/10.1097/01.pas.0000213351.49767.0f

Baylin, S. B. (2005). DNA methylation and gene silencing in cancer. Nature clinical practice Oncology, 2(1), S4-S11. https://doi.org/10.1038/ncponc0354

Baylin, S. B., \& Chen, W. Y. (2005, January). Aberrant gene silencing in tumor progression: implications for control of cancer. In Cold Spring Harbor Symposia on Quantitative Biology (Vol. 70, pp. 427-433). Cold Spring Harbor Laboratory Press. https://doi.org/10.1101/sqb.2005.70.010

Bertolo, C., Guerrero, D., Vicente, F., Cordoba, A., Esteller, M., Ropero, S., ... \& Lera, J. M. (2008). Differences and molecular immunohistochemical parameters in the subtypes of infiltrating ductal breast cancer. American journal of clinical pathology, 130(3), 414-424. https://doi.org/10.1309/J3QV9763DYPV338D 
Carey, L. A., Perou, C. M., Dressler, L. G., Livasy, C. A., Geradts, J., Cowan, D., et al. (2004). Race and the poor prognosis, basal-like breast cancer (BBC). Breast Cancers study. J Clin Oncol., (Suppl), abstr 9510. https://doi.org/10.1200/jco.2004.22.90140.9510

Carey, L. A., Perou, C. M., Livasy, C. A., Dressler, L. G., Cowan, D., Conway, K., ... \& Deming, S. L. (2006). Race, breast cancer subtypes, and survival in the Carolina Breast Cancer Study. Jama, 295(21), 2492-2502. https://doi.org/10.1001/jama.295.21.2492

Carvalho, F. M., Bacchi, L. M., Pincerato, K. M., Van de Rijn, M., \& Bacchi, C. E. (2014). Geographic differences in the distribution of molecular subtypes of breast cancer in Brazil. BMC women's health, 14(1), 102. https://doi.org/10.1186/1472-6874-14-102

Catteau, A., Harris, W. H., Xu, C. F., \& Solomon, E. (1999). Methylation of the BRCA1 promoter region in sporadic breast and ovarian cancer: correlation with disease characteristics. Oncogene, 18(11), 1957-1965. https://doi.org/10.1038/sj.onc.1202509

Colditz, G. A., \& Bohlke, K. (2014). Priorities for the primary prevention of breast cancer. CA: a cancer journal for clinicians, 64(3), 186-194. https://doi.org/10.3322/caac.21225

Costa, V. L., Henrique, R., Ribeiro, F. R., Pinto, M., Oliveira, J., Lobo, F., ... \& Jerónimo, C. (2007). Quantitative promoter methylation analysis of multiple cancer-related genes in renal cell tumors. BMC cancer, 7(1), 133. https://doi.org/10.1186/1471-2407-7-133

Devilee, P., \& Tavassoli, F. A. (2013). World Health Organization: Tumours of the breast and female genital organs. Oxford. UK: Oxford University Press.

Eccles, S. A., Aboagye, E. O., Ali, S., Anderson, A. S., Armes, J., Berditchevski, F., ... \& Bundred, N. J. (2013). Critical research gaps and translational priorities for the successful prevention and treatment of breast cancer. Breast Cancer Research, 15(5), R92. https://doi.org/10.1186/bcr3493

Esteller, M., Silva, J. M., Dominguez, G., Bonilla, F., Matias-Guiu, X., Lerma, E., ... \& Gabrielson, E. (2000). Promoter hypermethylation and BRCA1 inactivation in sporadic breast and ovarian tumors. JNCI: Journal of the National Cancer Institute, 92(7), 564-569. https://doi.org/10.1093/jnci/92.7.564

Fackler, M. J., McVeigh, M., Evron, E., Garrett, E., Mehrotra, J., Polyak, K., ... \& Argani, P. (2003). DNA methylation of RASSF1A, HIN-1, RAR- $\beta$, Cyclin D2 and Twist in in situ and invasive lobular breast carcinoma. International journal of cancer, 107(6), 970-975. https://doi.org/10.1002/ijc.11508

Goldhirsch, A., Winer, E. P., Coates, A. S., Gelber, R. D., Piccart-Gebhart, M., Thürlimann, B., ... \& Bergh, J. (2013). Personalizing the treatment of women with early breast cancer: highlights of the St Gallen International Expert Consensus on the Primary Therapy of Early Breast Cancer 2013. Annals of oncology, 24(9), 2206-2223.

Gonzalgo, M. L., Yegnasubramanian, S., Yan, G., Rogers, C. G., Nicol, T. L., Nelson, W. G., \& Pavlovich, C. P. (2004). Molecular profiling and classification of sporadic renal cell carcinoma by quantitative methylation analysis. Clinical cancer research, 10(21), 7276-7283. https://doi.org/10.1158/1078-0432.CCR-03-0692

Huang, X., Dugo, M., Callari, M., Sandri, M., De Cecco, L., Valeri, B., ... \& Daidone, M. G. (2015). Molecular portrait of breast cancer in $\mathrm{C}$ hina reveals comprehensive transcriptomic likeness to $\mathrm{C}$ aucasian breast cancer and low prevalence of luminal A subtype. Cancer medicine, 4(7), 1016-1030. https://doi.org/10.1002/cam4.442

Imam, B. A., Okechi, O. O., Abdullahi, K., Abubakar, U., Musa, A. B., Okorie, N., ... \& Ibrahim, K. K. (2017). Immunohistochemical pattern of breast cancer in Maiduguri, Borno state. Journal of Cancer and Tumor International, 1-10. https://doi.org/10.9734/JCTI/2017/31831

Kern, S. E. (2001). Progressive genetic abnormalities in human neoplasia. In: Mendelsohn, J., Howley, Pm, Israel, M. A. (eds.), The Molecular Basis of Cancer (2nd ed.). Philadelphia:WB Saunders;.p.41-69.

Larsen, M. J., Kruse, T. A., Tan, Q., Laenkholm, A. V., Bak, M., Lykkesfeldt, A. E., ... \& Thomassen, M. (2013). Classifications within molecular subtypes enables identification of BRCA1/BRCA2 mutation carriers by RNA tumor profiling. PloS one, 8(5). https://doi.org/10.1371/journal.pone.0064268

Lehmann, U., Celikkaya, G., Hasemeier, B., Länger, F., \& Kreipe, H. (2002). Promoter hypermethylation of the death-associated protein kinase gene in breast cancer is associated with the invasive lobular subtype. Cancer research, 62(22), 6634-6638. 
Magdinier, F., Ribieras, S., Lenoir, G. M., Frappart, L., \& Dante, R. (1998). Down-regulation of BRCA1 in human sporadic breast cancer; analysis of DNA methylation patterns of the putative promoter region. Oncogene, 17(24), 3169-3176. https://doi.org/10.1038/sj.onc.1202248

Majid, R. A., Hassan, H. A., Muhealdeen, D. N., Mohammed, H. A., \& Hughson, M. D. (2017). Breast cancer in Iraq is associated with a unimodally distributed predominance of luminal type B over luminal type A surrogates from young to old age. BMC women's health, 17(1), 27. https://doi.org/10.1186/s12905-017-0376-0

Matros, E., Wang, Z. C., Lodeiro, G., Miron, A., Iglehart, J. D., \& Richardson, A. L. (2005). BRCA1 promoter methylation in sporadic breast tumors: relationship to gene expression profiles. Breast cancer research and treatment, 91(2), 179-186. https://doi.org/10.1007/s10549-004-7603-8

Motoshita, J., Oue, N., Nakayama, H., Kuraoka, K., Aung, P. P., Taniyama, K., ... \& Yasui, W. (2005). DNA methylation profiles of differentiated-type gastric carcinomas with distinct mucin phenotypes. Cancer science, 96(8), 474-479. https://doi.org/10.1111/j.1349-7006.2005.00074.x

Nwafor, C. C., \& Keshinro, S. O. (2015). Pattern of hormone receptors and human epidermal growth factor receptor 2 status in sub-Saharan breast cancer cases: Private practice experience. Nigerian journal of clinical practice, 18(4), 553-558. https://doi.org/10.4103/1119-3077.156905

Nzegwu, M. A., Anyikam, A., Ozumba, B. C., Ugochukwu, A. I., \& Agu, K. (2008). Malignant breast diseases in Eastern Nigeria. Saudi Med J, 29(5).460-462.

Oboma, Y. I., Susan, B. E., Elesha, S. O., \& Jonathan, M. (2017). Breast cancer biomarkers at Niger delta university hospital: Comparisons with national and international trends and clinical significance. Pathophysiology, 24(3), 191-196. https://doi.org/10.1016/j.pathophys.2017.05.002

Olopade, O. I., Fackenthal, J. D., Dunston, G., Tainsky, M. A., Collins, F., \& Whitfield-Broome, C. (2003). Breast cancer genetics in African Americans. Cancer, 97(S1), 236-245. https://doi.org/10.1002/cncr.11019

Olopade, O., Oluwasola, O., \& Ebili, H. (2014). Molecular subtypes of breast cancer. Future Med., 13(2), 20-33. https://doi.org/10.2217/ebo.13.374

Omoniyi-Esan, G. O., Olaofe, O. O., Aremu, O. A., Omonisi, A. E., Olasode, B. J., \& Adisa, O. A. (2015). Hormonal and HER2 receptor Immunohistochemistry of Breast Cancers in Ile Ife, Nigeria. Austin J Women's Health, 2(1), 1009.

Rahib, L., Smith, B. D., Aizenberg, R., Rosenzweig, A. B., Fleshman, J. M., \& Matrisian, L. M. (2014). Projecting cancer incidence and deaths to 2030: the unexpected burden of thyroid, liver, and pancreas cancers in the United States. Cancer research, 74(11), 2913-2921. https://doi.org/10.1158/0008-5472.CAN-14-0155

Risinger, J. I., Maxwell, G. L., Berchuck, A., \& Barrett, J. C. (2003). Promoter hypermethylation as an epigenetic component in Type I and Type II endometrial cancers. Annals of the New York Academy of Sciences, 983(1), 208-212. https://doi.org/10.1111/j.1749-6632.2003.tb05975.x

Rosner, B., Glynn, R. J., Tamimi, R. M., Chen, W. Y., Colditz, G. A., Willett, W. C., \& Hankinson, S. E. (2013). Breast cancer risk prediction with heterogeneous risk profiles according to breast cancer tumor markers. American journal of epidemiology, 178(2), 296-308. https://doi.org/10.1093/aje/kws457

Rossai, J. (2004). Breast. In: Rosai and Ackerman's Surgical Pathology (9th ed., pp. 1763-1871.). New Delhi India: CV Mosby company.

Serrano-Gomez, S. J., Sanabria-Salas, M. C., Hernández-Suarez, G., García, O., Silva, C., Romero, A., ... \& Zabaleta, J. (2016). High prevalence of luminal B breast cancer intrinsic subtype in Colombian women. Carcinogenesis, 37(7), 669-676. https://doi.org/10.1093/carcin/bgw043

Seshie, B., Adu-Aryee, N. A., Dedey, F., Calys-Tagoe, B., \& Clegg-Lamptey, J. N. (2015). A retrospective analysis of breast cancer subtype based on ER/PR and HER2 status in Ghanaian patients at the Korle Bu Teaching Hospital, Ghana. BMC clinical pathology, 15(1), 14. https://doi.org/10.1186/s12907-015-0014-4

Tisserand, P., Fouquet, C., Barrois, M., Gallou, C., Dendale, R., Stoppa-Lyonnet, D., ... \& Soussi, T. (2003). Lack of HIN-1 methylation defines specific breast tumor subtypes including medullary carcinoma of the breast and BRCA1-linked tumors. Cancer biology \& therapy, 2(5), 559-563. https://doi.org/10.4161/cbt.2.5.511

Titloye, N. A., Foster, A., Omoniyi-Esan, G. O., Komolafe, A. O., Daramola, A. O., Adeoye, O. A., ... \& Lewis, P. D. (2016). Histological features and tissue microarray taxonomy of Nigerian breast cancer reveal 
predominance of the high-grade triple-negative phenotype. Pathobiology, 83(1), 24-32. https://doi.org/10.1159/000441949

Toyooka, S., Maruyama, R., Toyooka, K. O., McLerran, D., Feng, Z., Fukuyama, Y., ... \& Shimizu, N. (2003). Smoke exposure, histologic type and geography-related differences in the methylation profiles of non-small cell lung cancer. International journal of cancer, 103(2), 153-160. https://doi.org/10.1002/ijc.10787

Tryggvadottir, L., Sigvaldason, H., Olafsdottir, G. H., Jonasson, J. G., Jonsson, T., Tulinius, H., \& Eyfjörd, J. E. (2006). Population-based study of changing breast cancer risk in Icelandic BRCA2 mutation carriers, 1920 2000. Journal of the National Cancer Institute, 98(2), 116-122. https://doi.org/10.1093/jnci/djj012

Turner, N. C., Reis-Filho, J. S., Russell, A. M., Springall, R. J., Ryder, K., Steele, D., ... \& Tutt, A. N. (2007). BRCA1 dysfunction in sporadic basal-like breast cancer. Oncogene, 26(14), 2126-2132. https://doi.org/10.1038/sj.onc.1210014

Wolff, A. C., Hammond, M. E. H., Hicks, D. G., Dowsett, M., McShane, L. M., Allison, K. H., ... \& Hanna, W. (2014). Recommendations for human epidermal growth factor receptor 2 testing in breast cancer: American Society of Clinical Oncology/College of American Pathologists clinical practice guideline update. Archives of Pathology and Laboratory Medicine, 138(2), 241-256. https://doi.org/10.1200/JCO.2013.50.9984

\section{Copyrights}

Copyright for this article is retained by the author(s), with first publication rights granted to the journal.

This is an open-access article distributed under the terms and conditions of the Creative Commons Attribution license (http://creativecommons.org/licenses/by/4.0/). 